\title{
Brazil and South Africa: The Weak Links of the BRICS?
}

\author{
Agonnoude Bidoley Vianney Freddy ${ }^{1}$, Adohounde Yaovi Sylvestre ${ }^{1}$, Stepanov Sergey Aleksandrovich ${ }^{1}$ \& \\ Shulenina Nadezhda Viktorovna ${ }^{1}$ \\ ${ }^{1}$ Department of Political Analysis and Management, RUDN University, Moscow, Russia \\ Correspondence: Agonnoude Bidoley Vianney Freddy, RUDN University, 117198 Street Miklukho-Maklaya 13, \\ Moscow, Russia. E-mail: freddyagonnoude@mail.ru
}

Received: September 1, 2019

Accepted: October 11, 2019

Online Published: November 28, 2019

doi:10.5539/jpl.v12n4p15

URL: https://doi.org/10.5539/jpl.v12n4p15

\begin{abstract}
As the central role of the state in international relations is challenged, many new actors are emerging on the world stage. Today, there are a multitude of international organizations or groups of countries with considerable influence. Among the latter, the BRICS are drawing increasing attention with greater economic and political weight. Calling for the need to build a multipolar world, the ideological approach of the group of five dynamic world economies is intended to unite in a world marked by Western hegemony. It is important to note, however, that the five countries that make up the BRICS have their own specificities, which differentiates them from one another. Apart from the ideological constant that undeniably unites them, the BRICS are above all five distinct economies, five political systems, five foreign policies, to name but a few factors. The author uses a number of criteria to analyze the place of Brazil and South Africa in the BRICS. Referring to the weaknesses of these two countries, the author pays a close attention to their foreign policy approach in the context of BRICS' restructuring of the world order, as well as to the political scandals identified in the last decade at the top of these two countries.
\end{abstract}

Keywords: BRICS, Brazil, emerging countries, multipolar world, South Africa, world order

\section{Introduction}

The beginning of the 21 st century was marked by fundamental changes in world politics and world economy. This has resulted in a loss of position of the major economic powers to the benefit of some peripheral countries, which have since acquired an unusual and growing economic power. In a context of transformation of the global economic and political order, a specific term draws attention: the acronym BRICS. BRICS appears as an international intergovernmental organization comprising the Federative Republic of Brazil, the Russian Federation, the Indian Republic, the People's Republic of China and the Republic of South Africa (Brazil, Russia, India, China and South Africa). Coined in 2001 by Jim O'Neill, head of the Global Economic Research Department at Goldman Sachs, the term BRIC referred to the four rapidly growing global economies: Brazil, Russia, India and China. It was only after South Africa's integration in December 2010 that the group became BRICS.

Formally initiated after the Yekaterinburg Summit of June $16^{\text {th }} 2009$, the BRICS' main objective is to ensure the independence of member countries from global financial institutions. In addition, the group is developing gradually and transforming itself into a comprehensive long-term coordination mechanism on a number of key global economic and political issues. Many factors illustrate the prospects for the development of economic cooperation within the BRICS framework. These include the factor of economic growth, the factor of mutually beneficial cooperation in various sectors of the economy, the factor of democratic development and, of course, the ideological factor. The BRICS intend to work towards a transition from a unipolar world order to a global multipolar system. Thus, the intergovernmental organization appears to be a platform for dialogue and cooperation in a multipolar world. It should be noted that the BRICS are not an integration alliance because they do not have a common economic space. However, concrete measures have been taken within the group by member countries for the development of economic cooperation.

In a national context marked over the past decade by political scandals at the top of the state, Brazil and South Africa, within the BRICS group, undoubtedly represent the duo whose presidential leadership has suffered some failures. Apart from the political leadership criterion, there are a number of factors that allow these two BRICS 
members to be compared to the rest of the group. Assuming that these two countries would represent the weak links of the group on a number of points, this article analyses all the factors characterizing the position of Brazil and South Africa within the BRICS.

\section{Methodology}

The methodological basis of the article includes research approaches such as systemic approach, comparative analysis, structural analysis and policy analysis using inductive and deductive methods. Thanks to the systemic approach, it was possible to analyze and understand the problem of the polarity of the world system after the Second Cold War. This has enabled us to identify the characteristics of the multipolar system in the modern world. BRICS member countries are leaders in their regions and actively support initiatives to strengthen regional integration. The trend of regionalization in the context of globalization was also analyzed from the perspective of a systemic approach. In a comparative approach, various points of comparison were defined to determine the place of Brazil and South Africa in the BRICS.

\section{Main part}

\subsection{The Ideological Conception of the BRICS}

Within the limits of a bipolar confrontation, the United States and the Soviet Union sought to preserve their power balance, with mutual fear and mistrust leading the superpowers to seek allies and engage in an arms race. Countries that, for ideological reasons, did not ally with either of the superpowers have taken the path of non-alignment with the blocs and the development of the so-called Third World, alongside the socialists and capitalists (Nikitina, 2012). The end of the 20th century and the beginning of the 21 st century were marked by a systemic change of international relations and the global political structure. On one hand, the disintegration of the Soviet Union leading to the end of the Cold War offered a geopolitical advantage to the United States, which was able to extend and strengthen its domination throughout the world. On the other hand, following the remarkable rise of the new powers, the BRICs (Brazil, Russia, India, and China) at the beginning of the 21st century, the need to create alternative systems of global governance has become a hot topic in international relations. The unipolar world designed and governed by the United States and its allies has been challenged with ideological formatting. The member countries of the BRICS group undoubtedly show their inclination for the establishment of a multipolar world order, where various geopolitical and economic centers interact according to respect and consideration of each other's interests. BRICS thus offer alternative strategies for global governance and economic development. The institutionalization of their common interests therefore appears to be a response to attempts to preserve American economic hegemony. The word BRICS should therefore be seen today as the dawn of a new era, with the emergence of a large circle representing the new global power of the five developing countries, rich in human and material resources. These countries can also boast a rich history of civilization and culture.

\subsection{Brazil and South Africa: Foreign Policy Approach in the Context of BRICS Restructuring of the World Order}

Foreign policy combines national interests and values with universal human values and interests, in particular in cooperation, security and peace building, in order to solve international problems emerging on the path of social progress. (Zhukova, 1997). It is established that the five countries making up the BRICS share the ideology of restructuring the world order. In this context, the reform of the international governance system has risen to the top of the Group of Five's concerns, as the policy of the Bretton Woods institutions is no longer appropriate for the BRICS. The group therefore initiated its ideas for reforming these institutions. It should be stressed that polarity issues in the global system have a significant influence on the ideology of BRICS countries which are interested in developing multipolarity at the expense of unipolarity. To this end, the group, through various country leaders, has always demonstrated ideological solidarity on the issue. It should be noted that Brazil joined the BRICS under the chairmanship of Luiz Inácio Lula da Silva (2003-2010). Under Lula, Brazilian diplomacy has shown a rejection of the unipolar order, by actively working for a more balanced exercise in global governance (Howlett-Martin, 2012). But this orientation of foreign policy has its sources in the basic document of the Brazilian State. Indeed, in accordance with the Brazilian Constitution, the country's foreign policy respects a number of principles predefined in article 4, including the self-determination of peoples, equality between states and cooperation among peoples for the progress of humanity. It should be noted that these three principles are common to the BRICS and are often put back on the table by the latter when the opposite is observed in relations between States. Thus, with regard to BRICS, from Lula da Silva to Michel Temer (2016-2018) and Dilma Roussef (2011-2016), Brazil's position when it comes to its participation in the group has never been questioned. These different presidents have always followed the guidelines for participation in BRICS. However, the accession to power in January 2019 by Jair Bolsonaro has slightly changed the situation. The new Brazilian 
leader does not inspire the confidence of the "BRICS-optimists". The intentions to break with the foreign policy of its predecessors take all the necessary consideration. Indeed, Jair Bolsonaro sets as the anchor of his foreign policy a rapprochement with Washington. Its proximity to Donald Trump is perceived as a risk factor for cohesion within BRICS. However, this did not prevent him from taking part in the traditional BRICS Heads of State meeting on the sidelines of the last G20 summit in Osaka in June $28^{\text {th }}$ 2019. For his first participation in this informal meeting, the Brazilian leader then called on his peers to count on the dedication of his government to strengthen cooperation between the BRICS. It should also be noted that, as part of its rotating presidency, Brazil hosted the eleventh BRICS Summit in a few months' time. In this regard, Russian Foreign Minister Sergei Lavrov said in an interview on July $23^{\text {rd }} 2019$ to the Latin American media and the RT channel, "there is no reason to believe that Brazil will review its approaches based on principles of BRICS preservation and development, thus reflecting the realities of a multipolar world". According to the head of Russian diplomacy, the affirmation of Brazil's continued participation in BRICS, given by President Bolsonaro immediately after the elections, must be taken into account. Brazil's active preparation of the BRICS summit is also a positive sign not to be overlooked, according to Serguei Lavrov. It should therefore be stressed that the Bolsonaro administration's interests in the BRICS is therefore still relevant despite the general uncertainties highlighted. Another aspect of the uncertainty surrounding Bolsonaro's foreign policy, unlike that of South African President Cyril Ramaphosa, is Brazil's position on the political crisis in Venezuela. Indeed, the country, unlike its BRICS pairs (China and Russia in particular), has without hesitation expressed its support for Juan Guaidao, recognizing him as interim president of Venezuela. South Africa and India then refrained from taking a position. If previously the BRICS countries' votes at the United Nations on all the issues raised in the Security Council or the General Assembly were agreed on, the Brazilian votes on the Venezuelan crisis are illustrated as the first point of disagreement observed among the BRICS under Bolsonaro. As a reminder, on February $28^{\text {th }} 2019$, two divergent draft resolutions on the situation in Venezuela put forward by the United States and the Russian Federation were submitted to the United Nations Security Council. South Africa supported only the Russian resolution, voting against the American one. According to Pretoria, the content of the American resolution contradicts not only the Constitution and the fundamental principles of South Africa's foreign policy, but also the content and spirit of the United Nations Charter. The Russian Federation's resolution, on the other hand, contains elements in accordance with the principles of the Charter of the United Nations for the peaceful settlement of international disputes. The Russian resolution also reflected the principles of humanity, neutrality, impartiality and independence in the provision of humanitarian assistance. South Africa therefore voted in favour of the Russian Federation's resolution. It is important to note that Brazil's position on Venezuela is nevertheless contrary to one of the foreign policy principles established by the country's Constitution in article 4: the self-determination of people. This principle, which is often less taken into account in Western foreign policy doctrine, is quite present in the common dialectic of the BRICS in terms of challenging the unipolar world order. In short, it can be concluded that on a range of international issues, Cyril Ramaphosa with South Africa inspires confidence in the solidarity of the BRICS as a bloc, while Jair Bolsonaro on the Brazilian side leaves the doubt and uncertainty of a coordination of points of view.

\subsection{The Economic and Political Weight within the BRICS}

In a comparative approach, it should be noted that both economically and politically, the BRICS countries are not alike. Apart from the ideological constant that undeniably unites them, the BRICS are above all five economies that are distinct in size. Referring to the GDP ranking of countries according to the IMF in 2018, China, the world's leading economic power with USD 25270.07 billion, is at the top of the group, followed respectively by India (USD 10505.29 billion), Russia (USD 4213.40 billion), Brazil (USD 3365.34 billion) and South Africa (USD 789.42 billion) within the BRICS. It shows that China's GDP is equivalent to the total GDP of the other members of the group. On the international scene, the political weight of each of the countries that make up the BRICS also differs. However, their position as a regional power and a key player in the various sub regional organizations gives them a regional political weight that also manifests itself at the global level.

South Africa, the last of the BRICS countries in terms of economic size, however, enjoys the status of the second largest economy on the African continent and a regional political leader. The same is true for Brazil, which is the undisputed leader in Latin America.

It should be noted that Brazil has the merit of a history that demonstrates the technological power and innovative capacities of the State and its companies. In recent years, the country has been operating in the global market much more convincingly and actively than before. It is important to recall that Brazil has succeeded in creating a favorable economic environment around it. This was followed by pragmatic foreign policy results. The first major achievement was the creation of Mercosur, an integration block with potential in various fields, mainly in 
the economic and energy fields. All this testifies to the recognition of Brazil's economic and political power in Latin America. Thus, it seems appropriate to consider Brazil as the only country capable of assuming the role of an alternative pole in the space of the two Americas. For the BRICS, the country is therefore an ally of geostrategic importance in the region. In return, participation in BRICS has significantly improved Brazil's position in the international community.

In the case of South Africa, the importance of its BRICS membership goes beyond the economic aspect and is rather perceived as "the integration of an association of countries sharing the same values attached to their independence and wishing to reform the global decision-making structure" (Shubin, 2015). BRICS are therefore seen as a political and moral force capable of making the changes necessary to make the world a better place. South Africa intends to play its part, positioning itself as the African regional leader, the continent's representative in the group and vice versa. South Africa, like Brazil, draws on its position as an African regional power to assume its representative position of the African continent within the group. As part of the tenth BRICS Summit, held in July $28^{\text {th }} 2018$ in Johannesburg, Jacob Zuma's successor, Cyril Ramaphosa, with the support of his BRICS colleagues, invited African leaders to the table of five. Thus, the new President of South Africa reaffirmed his country's position regarding its role in BRICS-Africa relations. Cyril Ramaphosa said: "We felt the need to be a representative of Africa in the BRICS group. And we have used our participation as a lever to protect development and progress in Africa".

Another point of comparison of the economic weight within the BRICS is the financial contributions for the creation in 2015 of the New Development Bank of the BRICS. The creation of the NDB reflects the interest shown by BRICS Member States in creating the group's own reserve funds. A special phenomenon in the global financial and economic system, some researchers compare its appearance to the creation in 1991 of the European Bank for Reconstruction and Development (Ujvari, 2016). However, the Russian researcher Karataev S.V. considers such a comparison to be incorrect, despite the important reasons for the creation of the NDB (Karataev, 2017). According to him, the EBRD is a regional institution operating in a limited number of countries in Central and Eastern Europe, the Caucasus, Central Asia and North Africa, while the NDB is considered a world bank with no geographical restrictions in its activities. The formation of the New Development Bank in 2015 has shown a high potential for cooperation between BRICS countries. It should be noted that the NDB agreement provided for a series of agreements: China received the headquarters, India - the first president, Russia - the chairman of the board of governors, Brazil - the chairman of the board of directors, and South Africa - a subsidiary of the bank (Karataev, 2017). The creation of the NDB then appeared to be one of the key elements in the institutionalization of the BRICS group, which, through the bank, increased the financing of various infrastructure projects in the regions of member countries. With regard to the financial contributions for the creation of the bank, the differences according to some sources are significant. Out of an initial capital of USD 100 billion, this included a contribution of USD 41 billion for China, USD 18 billion each for Brazil, Russia and India, and USD 5 billion for South Africa. But according to information from the NDB itself, "the initial subscribed capital would have been USD 50 billion, divided equally among the founding members". The fact is that there is a predominance of Chinese finance, and a low South African financial contribution. However, the principle of equity prevails within the group with regard to the functioning of the NDB.

\subsection{Brazil and South Africa to Face Political Scandals at the Top of the State}

In the ten years of the BRICS' existence, Brazil and South Africa have distinguished themselves as the only members of the group whose executives have been seriously shaken by political crises, driven by repeated corruption scandals that have led to changes at the top of the state. In the case of Brazil, these dark hours in the country's political history date back to the presidency of Lula da Silva, who, it should be recalled, was the initiator of the country's new foreign policy line based on South-South cooperation, initially symbolized by the IBSA forum (India, Brazil, South Africa) and later by the BRICS group. The first Brazilian president from the working class, Lula da Silva is still recognized for his leadership. Indeed, international recognition of the status of regional power began under Luiz Inácio Lula da Silva. Nevertheless, the acts of corruption that stained his presidency have been engraved forever in his political legacy. The famous operation "Lava Jato" (Express Washing), the name given to the gigantic anti-corruption campaign launched in 2014 by the Brazilian federal authorities, resulted in charges and arrests that splashed the country's political landscape. After years of legal proceedings, former President Lula da Silva was sentenced in February 2019 to 12 years and one month in prison for corruption and money laundering. The second wave of political scandal resulted in the dismissal in 2016 by the Senate of Lula da Silva's successor, Dilma Roussef, convicted of a "crisis of responsibility". Her term of office, which was initially scheduled to end in 2018, was shortened in a case involving the concealment of public accounts in order to conceal the size of the deficit. She was also accused of signing decrees without 
parliamentary approval. In her defense, Dilma Roussef, like her predecessor, both members of the huge Workers' Party, claimed political reprisals, denouncing in her case an institutional coup d'état. The forced alternation that allowed Michel Temer to take over the interim until the end of his term in office resulted in the unpopularity of the Temer government, as the leader himself faced accusations of corruption and personal enrichment. It is important to note that the discredit thrown at the entire Brazilian political class served as a springboard for Jair Bolsonaro's populist strategy of conquering power. In his first 200 days of presidency, the latter has experienced the misfortune of the political scandals haunting Brazil. This statement refers to the seizure of $39 \mathrm{~kg}$ of cocaine on board an official Brazilian plane that accompanied the head of state to the G20 summit in Osaka. Even if the Brazilian president is neither of near nor by far involved in this case, the impact in terms of political image was inevitable. The BolsoNarcos hashtag that appeared on twitter says a lot about the impact of this case on Jair Bolsonaro's image.

As for South Africa, we obviously remember the case of Jacob Zuma (2009-2018). The former South African head of state, like his Brazilian counterparts Lula da Silva and Michel Temer, has been facing accusations of corruption in his country since his second term. The hearings of the "Zondo" inquiry commission revealed the existence of bribery systems practiced under the former president's regime, which was forced under pressure from his ANC party to resign in February 2018. It is important to remember that Jacob Zuma, like Lula da Silva, was the initiator of South Africa's integration into the BRICs.

All in all, it is worth noting that serious political scandals have marked the top of the Brazilian and South African states over the past decade. In a logic of "quality of power", it should be remembered that the international image of these two countries has been unequivocally damaged. There is thus a problem of quality of the leaders of these countries within the BRICS group. Nevertheless, the dynamics of both institutional and popular control observed in both countries make it possible to appreciate the manifestation of democracy in a context of good governance.

\subsection{Brazil and Its Far-Right President}

A candidate of the far right and the Social Liberal Party, Jair Bolsonaro came to power in a rather complex Brazilian socio-political context, marked in part by the politicization of social inequalities, the frequency of cases of corruption and political scandals at the top of the state, and the rise of populism on a global scale. With 55.2\% of the vote against $44.8 \%$ for his rival, the current President of Brazil has seen his clearly populist campaign strategy paying off. The alchemy of "bolsonarism" is also reflected in the massive support of evangelical, conservative and ultraliberal Christians (Christophe Ventura, 2018). Promising to change Brazil's destiny, Jair Bolsonaro's rise to power symbolizes the political transfer to a Brazil weakened by extreme right-wing moods. Bolsonaro's candidacy was supported in a social context of rejection of any initiative of the Workers' Party which totaled thirteen years in power and to whom Camp Bolsonaro was able to impute the country's economic and social crisis. Bolsonaro's questioning of Brazilian democracy also has its source in the populist maneuver of man. When we know that populism aims to renew democracy from within by representing all those excluded by the democracy in place (Federico Tarragoni, 2018), we better understand the effectiveness of Bolsonaro's populist strategy. Highly brilliant in his homophobic, sexist and racist statements, the new president thus displays a degrading image of a Brazilian leadership that is now in the spotlight. The BRICS-optimists see this as a problem when we know that far-right rhetoric is practically not present among Bolsonaro's colleagues in the BRICS. The political orientation of President is therefore probably another point of difference with the latter.

\subsection{South Africa and Xenophobia}

South Africa's history, sadly linked to apartheid, still has its after-effects. Even though this racist regime has ended since 1994, the rainbow nation has for decades been trapped by another previously incurable evil: chronic xenophobia. Indeed, since the fall of apartheid, the country has experienced a series of xenophobic eruptions between 2008, 2015, 2017 and most recently in February and september 2019. In a social context marked by class inequality, unemployment, poverty, corruption and injustice, the layers involved very easily adopt the extreme right-wing rhetoric of accusing foreigners of all evils. Thus, many foreign nationals, starting with African migrants, become the victims of this incurable disease. The passivity of South African elites for decades in addressing the problem suggests a guilty silence on the part of the South African elites. Promoting national identity, border security, and actions in the interests of South Africans, Mario Khumalo launched a new political party "South Africans First" in December 2016. Even if the latter claims not to be xenophobic, his political vision animates the "anti-foreigner" feeling recognized as the source of the evil in question. Moreover, in the run-up to the last elections in 2019, the theme of immigration was quite present in the speeches of the various candidates. The latter's about-face on the xenophobic actions of their electorate testifies to the manipulation of 
the situation. It should be noted that in a country recognized throughout the world for its democracy and its struggle for human rights, the xenophobic issue should be treated with much greater seriousness and rigor. Unless, as pointed out above, the rulers have made it a subject of political recuperation, giving carte blanche to the populist rhetoric. The result is that this crisis of leadership in the face of the xenophobic question is negatively reflected in the image of the country whose "political quality" has played a major role in its integration into the BRICS.

\section{Conclusion}

In this article, it is important to identify the many factors that explain the emergence of BRICS. After the collapse of the USSR, the unipolar model established in the world was no longer suitable for global governance. Since then, financial structures have pursued a policy that has so far served only the interests of developed countries. The World Bank, WTO and IMF were created as part of the Bretton Woods system after the Second World War and were supposed to guarantee global economic stability, but since the 1970s, all these institutions have become ideologically inclined towards neo-colonial politics and market extremism. The BRICS thus appear as this new axis of the multipolar world opting for alternative strategies of global governance.

The comparative study of Brazil and South Africa as BRICS member countries has enabled us to identify a number of parameters that have both a positive and a negative impact on their place in the group.

Brazil's foreign policy approach in the context of a restructuring of the world order by the BRICS is being challenged by President Jair Bolsonaro's orientation. Even if the latter remains in favor of Brazil's participation in BRICS, the guarantee of non-turbulence is almost non-existent. To this end, the country's political institutions and forces involved in foreign policy issues must work to ensure that Brazil-BRICS remains on course. This may, for example, result in the strengthening of normative texts on the subject.

South Africa must take the xenophobic issue seriously because it negatively affects its international image. The South African government must take its responsibility to ensure the safety of foreign nationals in the country. This is important for its position as a country that defends human rights.

In order to address the problem of recurrence of political scandals at the top of the state, it is important to strengthen control mechanisms in order to prevent this from happening. However, the dynamics of both popular and institutional control in both countries are already a good sign.

\section{References}

At the BRICS Summit in Johannesburg, Africa is at the center of attention. RFI. (2018). Retrieved July 23, 2019, from

http://www.rfi.fr/afrique/20180728-economie-reunion-brics-afrique-honneur-johannesburg-afrique-sud

Constitution the Federative Republic of Brazil 1988. The Federal Senate. Retrieved July 23, 2019, from http://www2.senado.leg.br/bdsf/bitstream/handle/id/243334/Constitution_2013.pdf?sequence=11\&isAllowe $\mathrm{d}=\mathrm{y}$

Department of international relations and cooperation of South Africa. Media Statement, 28 February 2019. South Africa reaffirms support for inclusive, political dialogue in Venezuela at the UN Security Council. Retrieved July 23, 2019, from http://www.dirco.gov.za/docs/2019/unsc0301.htm

Karataev, S. V. (2017). New development bank in the international coordinate system. National Strategy Issues, (2), 106-134.

Lavrov commented on Brazil's actions under the BRICS. Interview Ria Novosti. (2019). Retrieved July 23, 2019, from https://ria.ru/20190723/1556815787.html?Fbclid=IwAR3qoruA2WFoRbgBTyJh29JwIKoo1I30AifPOV 383vKYNzaURCJnoqhkPfg

Liste des pays par PIB (PPA). (2018). In Wikipedia, the free encyclopedia. Retrieved July 23, 2019, from https://fr.wikipedia.org/wiki/Liste_des_pays_par_PIB_(PPA)\#cite_note-Le_FMI_ne_veut_pas_admettre_qu e_la_Chine_est_la_premi\%C3\%A8re_\%C3\%A9conomie_mondiale-2

New Development Bank. Retrieved July 24, 2019, from https://www.ndb.int/about-us/

Nikitina, Yu. A. (2012). International relations and world politics: introduction to the specialty. Aspect Press.

Patrick, H.-M. (2012). Brazil's foreign policy of Lula. L'Harmattan.

Permanent Mission of South Africa to the United Nations. Explanation of Vote by South Africa at the UN Security Council vote on the Situation in Venezuela, 28 February. Retrieved July 23, 2019, from 
https://www.southafrica-newyork.net/pmun/statements\%202019/UNSC_EOV_venezuela_20190228.html

Shubin, V. G. (2015). South Africa in the BRICS: the last in order, but not least. World economy and international relations, (2), 230. https://doi.org/10.17323/1996-7845-2015-02-229

Tarragoni Federico. (2018). Bolsonaro, populiste ou néo-fasciste? L'express. Retrieved July 23, 2019, from https:/www.lexpress.fr/actualite/monde/amerique-sud/bolsonaro-populiste-ou-neo-fasciste_2045141.html

Ujvari, B. (2016). The European Union and the China-led Transformation of Global Economic Governance. Egmont Paper 85. Royal Institute for International Relations. June 2016. Retrieved July 24, 2019, from http://www.egmontinstitute.be/eu-and-chine-led-transformation-of-econ-governance

Ventura Christophe. (2018). Bolsonaro, le populiste qui a su séduire les élites économiques. Le Figarot. $\begin{array}{llll}\text { Retrieved July 23, 2019, from } & \text { 23, }\end{array}$ http://www.lefigaro.fr/vox/monde/2018/10/29/31002-20181029ARTFIG00244-bolsonaro-le-populiste-qui-a -su-seduire-les-elites-economiques.php

Zhukova, V. I., \& Krasnova, B. I. (1997). General and applied political science. Publishing House "Union".

\section{Copyrights}

Copyright for this article is retained by the author(s), with first publication rights granted to the journal.

This is an open-access article distributed under the terms and conditions of the Creative Commons Attribution license (http://creativecommons.org/licenses/by/4.0/). 